\title{
Kearifan Lokal Masyarakat Dalam Mitigasi Bencana Tsunami
}

\author{
Wita R. Kusuma ${ }^{*}$, Achmad S. Ramadhan ${ }^{1}$, Qurrota 'Aini ${ }^{1}$, Ade Suryanda ${ }^{1}$ \\ ${ }^{1}$ Program Studi Pendidikan Biologi, Universitas Negeri Jakarta
}

Kata Kunci:

kearifan lokal, mitigasi, tsunami

\begin{abstract}
Abstrak
Provinsi Nangroe Aceh Darussalam pernah dilanda tsunami. Tsunami terjadi akibat dari fenomena alam seperti aktivitas gempa bumi, letusan gunung berapi, dan longsor bawah laut. Peringatan dini bencana alam, khususnya tsunami penting untuk meminimalisir korban dan kerugian yang ditimbulkan. Kearifan lokal masyarakat setempat atau wilayah berdampak merupakan salah satu cara mitigasi tsunami. Mitigasi tsunami tidak selalu hanya berkaitan dengan teknologi, melainkan ada sudut pandang sosial dan budaya yang juga memiliki peran penting. Dengan latar belakang tersebut, tujuan disusunya artikel ini adalah untuk memahami permasalahan penerapan sistem peringatan dini tsunami di Indonesia serta melihat dampak dari kearifan lokal masyarakat setempat sebagai salah satu bentuk mitigasi tsunami melalui studi literatur.
\end{abstract}

Keywords:

local wisdom,

mitigation, tsunami

\begin{abstract}
Nangroe Aceh Darussalam Province was hit by a tsunami. Tsunamis occur as a result of natural phenomena such as earthquake activity, volcanic eruptions, and underwater landslides. Early warning of natural disasters, especially tsunamis is important to minimize casualties and losses caused. Lokal wisdom of local communities or impact areas is one way of tsunami mitigation. Tsunami mitigation is not always related to technology, but there are social and cultural perspectives that also have an important role. With this background, the purpose of this article is to understand the problem of implementing a tsunami early warning system in Indonesia and to see the impact of local wisdom of the local community as a form of tsunami mitigation through literature studies.
\end{abstract}

\section{1}

\section{PENDAHULUAN}

Sejarah tsunami yang telah melanda Indonesia cukup banyak, baik tsunami kecil sampai yang menelan ratusan ribu korban jiwa dan menimbulkan kerugian yang besar. Pada tanggal 26 Desember 2004, di Provinsi Nangroe Aceh Darussalam terjadi tsunami yang menewaskan lebih dari 200 ribu juta jiwa dan kerugian harta benda yang sangat besar
(Bambang, 2005). Sebagian besar bangunan yang ada porak poranda dilanda tsunami dan perlu waktu dan biaya untuk membangunnya kembali. Tsunami tersebut terjadi karena adanya gempa bumi tektonik berkekuatan 9 SR di Pulau Simeulue, Aceh dan menimbulkan tsunami terbesar sepanjang sejarah Indonesia (Bambang, 2005). Sejak saat itu, masyarakat Indonesia mulai menyadari ancaman dari tsunami dan perlunya langkah-langkah mitigasi

\footnotetext{
*Penulis koresponden: WitaRamadhiantyKusuma 1304617071@mhs.unj.ac.id
} 
untuk meminimalisir korban dan kerugian yang disebabkan oleh tsunami.

Tsunami berasal dari Bahasa Jepang dimana $t s u$ adalah pelabuhan dan name adalah gelombang, jadi tsunami adalah gelombang tinggi yang menghantam pantai. Tsunami sering disebabkan oleh gempa tektonik besar karena pergerakan patahan atau fraktur meluas secara vertikal sehingga air laut tersedot ke dalam fraktur dan kemudian dibuang kembali setelah fraktur mencapai kondisi keseimbangan (Baeda et al, 2015). Dalam kasus perambatan tsunami, kecepatan air bisa mencapai ratusan kilometer per jam. Antara gempa dan tsunami ada jeda waktu yang bisa digunakan untuk memberikan peringatan dini kepada publik. Mitigasi Tsunami perlu diberikan peringatan dini sebelum bencana (Baeda et al, 2015). Mitigasi adalah serangkaian upaya untuk mengurangi risiko bencana, baik melalui pembangunan fisik maupun penyadaran dan peningkatan kemampuan menghadapi ancaman bencana (Pasal 1 ayat 6 PP No 21 Tahun 2008 Tentang Penyelenggaraan Penanggulangan Bencana).

Gelombang tsunami dihasilkan oleh beberapa fenomena yang menyebabkan gangguan besar-besaran dari permukaan laut. Mekanisme tsunami yang paling sering adalah karena aktivitas gempa bumi, letusan gunung berapi, dan proses tanah longsor di lingkungan bawah laut dan pesisir. Tsunami tidak hanya menghantam Samudra Pasifik dan India tetapi juga seluruh bagian lautan global termasuk wilayah Eropa dan Mediterania. Pelajaran yang dapat diambil dari tsunami besar tahun 2004 di Samudera Hindia dan tahun 2011 di Jepang Timur Laut telah secara signifikan memengaruhi pengembangan studi tsunami dan tindakan mitigasi risiko dalam skala global. Masalah peringatan dini tsunami adalah topik hangat yang berkembang pesat di bidangbidang seperti sains, teknologi, perencanaan darurat, kesadaran, pendidikan, dan manajemen krisis semuanya berkontribusi dalam sinergi untuk melindungi masyarakat pesisir.

Kearifan lokal ternyata juga memiliki peran dalam peringatan dini tsunami bagi masyarakat sekitarnya. Sebelum tsunami Aceh pada desember 2004 silam, ternyata Aceh khususnya wilayah Pulau Simeulue juga pernah dilanda gempa bumi yang disusul oleh tsunami besar pada tahun 1907 (Natawdjaja, 2015). Jumlah kematian yang relatif rendah di Pulau Simeuleu Indonesia, yang dekat dengan pusat gempa, sebagian disebabkan oleh hutan bakau di sekitarnya dan kearifan lokal mereka. Dari keseluruhan populasi pulau tersebut hanya 7 orang yang meninggal akibat tsunami pada Desember 2004 (McAdoo et al, 2006). Masyarakat Pulau Simeulue mengenal tsunami dengan istilah "smong" yang merupakan kearifan lokal yang dipercaya oleh masyarakat sekitar (Kurniasih et al, 2020).

Smong ini biasa diceritakan secara turun temurun dengan berbagai cara, misalnya melalui cerita daerah, melalui lagu pengantar tidur, dan melalui senandung. Masyarakat Pulau Simeulue memahami smong sebagai gelombang besar yang terjadi setelah gempa. Sebelum datangnya smong, ada pertanda yang dapat diketahui seperti surutnya air laut setelah gempa besar dan adanya suara gemuruh. Jika pertanda ini muncul, maka masyarakat Pulau Simeulue ini diajarkan untuk menyelamatkan diri dengan cara tidak mendekati daerah pesisir dan segera menuju ke tempat yang lebih tinggi seperti puncak bukit.

Karena pemahaman yang telah ditanamkan turun temurun dari kakek nenek mereka, maka masyarakat sekitar telah tahu bagaimana tsunami ini akan muncul dan bagaimana upaya yang harus dilakukan ketika bencana ini muncul. Hal ini secara tidak langsung menjadi suatu upaya tradisional sebagai peringatan dini tsunami dan mengurangi dampak bencana.

Tujuan dari penelitian ini adalah untuk menyelidiki mitigasi bencana tsunami dengan pendekatan kearifal lokal di Indonesia, bahwa dalam mempersiapkan diri dari bencana khsususnya tsunami tidak hanya mengandalkan teknologi tetapi ada juga sudut pandang sosial dan budaya masyarakat.

\section{METODE PENELITIAN}

Metode yang digunakan dalam penelitian ini adalah studi literatur dengan cara membaca, mempelajari, dan mengkaji literaturliteratur yang berhubungan dengan bencana alam, kearifan lokal, tsunami, dan mitigasinya yang bertujuan untuk menganalisis pengetahuan yang dipublikasikan melalui ringkasan, klasifikasi, artikel teoritis, serta perbandingan studi penelitian sebelumnya. Sumber pustaka yang digunakan meliputi buku, jurnal, serta situs-situs internet. 
3

HASIL DAN PEMBAHASAN

\section{Proses Terbentuknya Tsunami}

Tsunami terjadi karena adanya patahan lempeng dasar laut yang menyebabkan gempa bumi dan mengganggu keseimbangan air sehingga timbulah gelombang besar. Gempa yang dapat menyebabkan tsunami biasanya memiliki frekuensi di atas 7,0 skala magnitudo. Selain secara tektonik, tsunami juga terjadi secara vulkanik. Tsunami secara vulkanik disebabkan oleh aktivitas gunung berapi yang masih aktif misalnya adanya pergerakan bibir gunung berapi atau letusan di dalam laut sehingga tercipta gelombang besar.

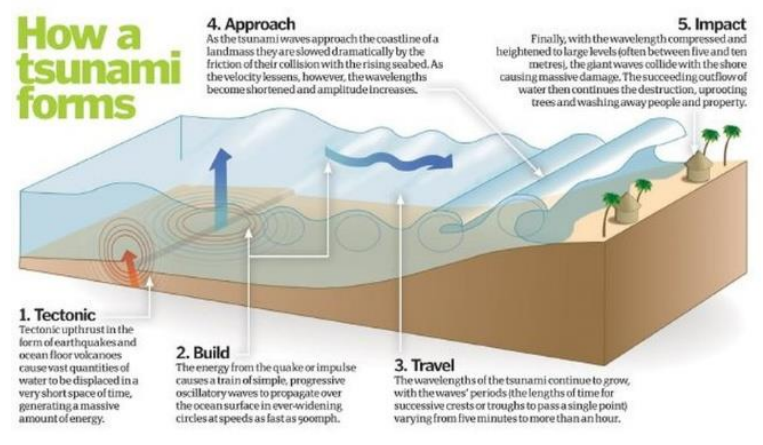

Gambar 1. Proses terjadinya tsunami secara teknonik (Sumber : jkgeography.com)

\section{Mitigasi Tsunami Secara Umum}

Mitigasi merupakan upaya atau kegiatan yang ditujukan untuk mengurangi dampak bencana alam atau buatan manusia bagi bangsa atau masyarakat (Carter, 1992). Menurut Pasal 1 ayat 6 PP No 21 Tahun 2008 Tentang Penyelenggaraan Penanggulangan Bencana, mitigasi merupakan serangkaian upaya untuk mengurangi risiko bencana, baik melalui pembangunan fisik maupun penyadaran dan peningkatan kemampuan menghadapi ancaman bencana.

Untuk upaya mitigasi tsunami, perlu diketahui terlebih dahulu bahaya tsunami dan dampak yang akan ditimbulkan oleh tsunami. Dalam penelitiannya, Imamura telah mengkaji mitigasi tsunami yang terintegrasi secara komprehensif di Padang. Perlu adanya peta evakuasi yang lengkap dan informatif. Peta evakuasi akan membantu masyarakat untuk mengamankan diri dari bencana dengan melihat peta tersebut. Peta yang lengkap adalah peta yang memiliki petunjuk posko keamanan, rute evakuasi dan jangkauan gelombang tsunami.

Sudah ada beberapa teknologi yang dapat memprakirakan tsunami seperti yang dikembangkan oleh Titov dkk. Pengembangan prakiraan tsunami oleh Titov dkk mengombinasikan data real-time tsunami dengan model numerik untuk memperhitungkan waktu spesifik terjadinya tsunami dan intensitas bahaya yang ditimbulkan.

Dalam mitigasi tsunami, perlu dilakukan analisis kerawanan tsunami sesuai dengan data gempa dan tsunami yang pernah terjadi di suatu daerah (Ihsan, 2017). Selain kerawanan, kerentanan tsunami di suatu daerah juga mempengaruhi tingkat risiko tsunami. Menurut Badan Nasional Penanggulangan Bencana, faktor kerentanan bencana antara lain kerentanan fisik, kerentanan sosial, kerentanan ekonomi dan kerentanan lingkungan.

\section{Kearifan Lokal Masyarakat dalam Mitigasi Tsunami}

Tidak hanya lingkungan yang diperbaiki tetapi juga pengetahuan masyarakat terhadap evakuasi bencana tsunami juga harus ditingkatkan. Hal ini dapat dilakukan dengan sosialisasi dan meningkatkan kesadaran masyarakat mengenai bencana alam dan kerusakan lingkungan yang ditimbulkan, mengembangkan informasi bencana dan kerusakan yang ditimbulkan termasuk pengembangan basis data dan peta resiko bencana, menggali berbagai kearifan lokal dalam mitigasi bencana (Jokowinarno, 2011).

Kearifan lokal merupakan semua bentuk pengetahuan, keyakinan, pemahaman atau wawasan serta adat kebiasaan atau etika yang menuntun perilaku manusia dalam kehidupan di dalam komunitas ekologi. Kearifan lokal atau tradisional tidak hanya menyangkut pengetahuan dan pemahaman masyarakat mengenai manusia dan membangun relasi di antara penghuni komunitas ekologis, tetapi membantu manusia dalam melakukan atau bertindak ketika melakukan pengelolaan lingkungan dan sumberdaya alam (Stanis, 2007).

Contoh kearifan lokal yang ada di Indonesia adalah cara masyarakat Pulau Simeulue dalam memberikan informasi tentang 
tsunami yang disebut dengan "smong" di daerah tersebut melalui cerita rakyat. Cerita rakyat yang diajarkan turun termurun cukup mendidik masyarakat untuk melakukan mitigasi ketika bencana tsunami datang menimpa pulau tersebut. Dari hasil penelitian yang dilakukan oleh McAdoo dkk di tahun 2006, hanya ada 7 orang yang menjadi korban jiwa dari tsunami tersebut. Cerita turun temurun tersebut berisi tentang tanda-tanda kemunculan tsunami, sehingga masyarakat dapat mencegah jatuhnya korban jiwa dengan naik ke tempat yang lebih tinggi.

Selain contoh dari mitigasi tsunami di masyarakat Pulau Simeulue, masyarakat di pesisir pantai di Pariaman, Padang, menggunakan mitos sebagai upaya mitigasi tentang kemunculan suatu bencana alam. Maharani dkk (2019) meneliti tentang upaya mitigasi yang dilakukan di pesisir pantai Pariaman, menurut sumber, mitigasi bencana berupa cerita (mitos) yang disampaikan secara turun menurun, seperti hewan-hewan seperti burung di sekitar pantai akan terbang secara acak disertai dengan suara ribut. Hubungan dengan alam sekitar juga menjadi upaya mitigasi ketika ada sesuatu yang janggal, seperti ketika menginjak tanah, tanah terasa kosong, juga bentuk awan berupa garis-garis lurus merupakan tanda sebuah bencana alam akan datang yang diajarkan (Maharani, 2019).

Masyarakat di Tana Ai, Nusa Tenggara Timur juga menggunakan hal yang sama untuk mitigasi bencana gempa bumi tektonik yang memicu tsunami. Mereka membuat cerita tentang Nepar (kura-kura) sebagai simbol magma gunung api dan dua naga raksasa yang melambangkan tanah dan air. Jika naga yang melambangkan tanah menggeliat, maka Nepar akan terguncang dan naga yang melambangkan air juga ikut bergerak. Gerakan dari naga simbol air akan menyebakan gelombang air yang disebut tsunami (Angin, 2019).

Penyampaian mitigasi tsunami yang dilakukan masyarakat memiliki jalan cerita yang berbeda, tetapi ada makna yang sama di setiap penyampaiannya. Cerita yang disampaikan oleh para leluhur dari masingmasing daerah memiliki makna bahwa sebelum adanya suatu bencana, pasti terdapat tandatanda yang dapat dirasakan oleh indera manusia. Pesan moral yang terkandung dalam cerita-cerita tersebut adalah kerjasama yang baik antara manusia dengan sesamanya. Tidak ada sikap saling curiga, saling menjatuhkan, dan menyampaikan berita bohong (Angin, 2019).

\section{PENUTUP}

Tsunami terjadi akibat dari patahnya lempeng bumi di dasar laut yang menyebabkan gempa bumi dan mengganggu keseimbangan air sehingga timbulah gelombang besar. Hampir semua kasus bencana tsunami menelan korban yang tidak sedikit begitu juga dengan kerugian harta benda. Pemanfaatan teknologi sebagai salah satu upaya mitigasi tsunami tentunya sudah banyak dilakukan sebagai peringatan agar penduduk wilayah yang terdampak dapat menyelamatkan diri secara cepat dan tepat serta mengurangi berbagai dampak yang ditimbulkan dari bencana tsunami.

Dari bencana tsunami yang terjadi di Aceh pada Desember 2004, kita mengetahui bahwa sistem peringatan dini khususnya di Indonesia belum dapat meminimalisir korban jiwa dan kerugian. Kesiapsiagaan masyarakat terhadap tsunami mungkin masih tergolong rendah sehingga ketika tsunami terjadi, masyarakat tidak dapat menyelamatkan diri. Di sisi lain, Pulau Simeulue yang juga merupakan wilayah terdampak dari bencana tsunami tersebut, menelan korban jiwa yang relatif rendah. Kearifan lokal yang dipercaya turun temurun menyelamatkan mereka. Smong yang dipahami masyarakat sekitar sebagai tsunami, telah menambah pemahaman mereka tentang bagaimana itu terjadi dan apa yang harus dilakukan jika pertanda bencana itu datang.

Kearifan lokal di daerah lain seperti di pesisir Pariaman dan Tana Ai juga menambah pemahaman masyakarat tentang tanda-tanda akan datangnya bencana alam. Belajar dari kearifan lokal di Pulau Simeulue, pesisir Pariaman, dan Tana Ai sebagai sistem peringatan dini tsunami, membuktikan bahwa upaya mitigasi tsunami tidak hanya dengan teknologi, tetapi juga diperlukan pendekatan sosial budaya untuk meningkatkan kewaspadaan masyarakat terhadap tsunami.

\section{DAFTAR PUSTAKA}

Alam, Q., \& Kusumasari, B. (2012). Local Wisdom-Based Disaster Recovery Model in Indonesia. Disaster Prevention and Management: An 
International Journal, 21(3), 351-369. Doi:10.1108/09653561211234525 .

Angin, I. S. (2019). Mitigasi Bencana Gempa Bumi Tektonik Pembangkit Tsunami Berbasis Kearifan Lokal Guyub Masyarakat Tana Ai Era Revolusi Industri 5.0 Kabupaten Sikka Provinsi Nusa Tenggara Timur. Manajemen Bencana di Era Revolusi Industri 5.0, 307-314.

Baeda, Rachman, Suriamihardja, \& Umar. (2015). Mitigation Plan for Future Tsunami of Seruni Beach Bantaeng. Procedia Earth and Planetary Science, 179- $185 . \quad$ Doi: 10.1016/j.proeps.2015.07.099.

Bryant. (2014). Tsunami : The Underrated Hazard. New York: Springer.

Christanto, J. (2011). Gempa Bumi, Kerusakan Lingkungan, Kebijakan dan Strategi Pengelolaan. Yogyakarta: Liberty Yogyakarta.

Correia, A. S. (2017). Tsunami mitigation in Japan after the 2011 Tōhoku Tsunami. International Journal of Disaster Risk Reduction, 22, 397411.doi:10.1016/j.ijdrr.2017.02.00.

Ihsan, F., \& Pramukanto, Q. (2017). Perencanaan Lanskap Kota Pariaman Provinsi Sumatera Barat Berbasis Mitigasi Tsunami. Jurnal Lanskap Indonesia, 9(1), 1-12. Doi: 10.29244/jli2017911-12.

Imamura, F., Mas, E., Muhari, A., Post, J., Pradono, M. H., \& Sugimoto, M. (2012). Tsunami Disaster Mitigation by Integrating Comprehensive Countermeasures in Padang City, Indonesia. Journal of Disaster Research, 7(1), 48-64. Doi: 10.29244/jli20127148-64.

Jokowinarno, D. (2011). Mitigasi Bencana Tsunami di Wilayah Pesisir Lampung. Jurnal Ilmiah Fakultas Teknik Universitas Lampung, 15(1), 13-20. ISSN: 0852-7733.

Kurniasih, A., Marin, J., \& Setyawan, R. (2020). Belajar dari Simeulue: Memahami Sistem Peringatan Dini Tsunami di Indonesia. Jurnal Geosains dan Teknologi, Vol. 3, No. 1. DOI: https://doi.org/10.14710/jgt.3.1.2020.2 $1-30$.

Maharani, S., Firman, F., \& R, R. (2019). Kearifan Lokal Masyarakat Pesisir
Dalam Mitigasi Bencana Di Kota Pariaman. Jurnal Pendidikan Tambusai, 3(3), 1591-1597. Retrieved from

https://jptam.org/index.php/jptam/articl e/view/406.

Marfai, M. A. (2013). Pengantar Etika Lingkungan dan Kearifan Lokal. Yogyakarta: UGM Press.

Marwanta, B. (2005). Tsunami Di Indonesia Dan Upaya Mitigasinya. Alami : Jurnal Teknologi Reduksi Risiko Bencana, vol. 10, no. 2. Doi: 10.1016/j.ijdrr.2015.10.02.

McAdoo, B. G., Dengler, L., \& Prasetya, G. (2006). Smong: How an Oral History Saved Thousands on Indonesia's Simeulue Island during the December 2004 and March 2005 Tsunamis. Earthquake Spectra, 661-669. doi:10.1193/1.2204966 .

Natawidjaja, D. H. (2015). Siklus MegaTsunami Di Wilayah Aceh-Andaman Dalam Konteks Sejarah. Pusat Penelitian Geoteknologi LIPI Journal RISET Geologi dan Pertambangan, 25 (1), 49-62.

Nick, C. W. (2008). Disaster management: A disaster manager's handbook. Mandaluyong City: Asian Development Bank.

Priyana, Y. (2008). Dasar-dasar Meteorologi dan Klimatologi. Surakarta: diktat kuliah. Surakarta: Diktat Kuliah.

S,A.P. (2009). Panduan Praktis Menghadapi Bencana. Yogyakarta: Kanisius.

Sartini. (2009). Mutiara Kearifan Lokal Nusantara . Yogyakarta: Kepel.

Sopaheluwakan, J. (2006). Kajian Kesiapsiagaan Masyarakat dalam Menghadapi Bencana Gempa Bumi dan Tsunami. Jakarta: Lembaga Ilmu Pengetahuan Indonesia.

Stanis, S., Supriharyono, \& Bambang, A. N. (2007). Pengelolaan Sumberdaya Pesisir Dan Laut Melalui Pemberdayaan Kearifan Lokal Di Kabupaten Lembata Propinsi Nusa Tenggara Timur. Jurnal Pasir Laut, 2(2), 67-82.

Stein, S., \& Okal, E. A. (2005). Seismology: speed and size of the Sumatra earthquake. Nature, 581-582. doi:10.1038/434581a. 
Suparmini, S., Setyawati, S., \& Sumunar, D. S. (2014). Mitigasi Bencana Berbasis Kearifan Lokal Masyarakat Baduy. Jurnal Penelitian Humaniora, Vol 19, No.1.

Usman, F., Kurniawan, E. B., \& K. M. (2014). Study on Reducing Tsunami Inundation Energy by the Modification of Topography based on Local Wisdom. Procedia Environmental Sciences, 20, 642-650. doi:10.1016/j.proenv.2014.03.077.

Wanger, T. C., Ainun, N., Brook, B. W., Friess, D. A., Oh, R. R., Rusdin, A., Tjoa, A. (2019). Ecosystem-Based Tsunami Mitigation for Tropical Biodiversity Hotspots. Trends in Ecology \& Evolution, 35, 96-100. Doi: 10.1016/j.tree.2019.10.008. 